\title{
Fernando Correia Dias, lições de silêncio e sabedoria
}

1. Professora de Sociologia (UnB). E-mail: mveloso@ unb.br

Mariza Veloso ${ }^{1}$

$\mathrm{P}$ rofessor Fernando - mestre paciente, generoso - e possuidor de uma profundidade serena - sempre soube construir o caminho, pedra por pedra, com solidez, embora, muitas vezes, tenha precisado trilhar tortuosas rotas, respirando os ventos da sofreguidão.

Muitos foram os obstáculos institucionais que enfrentou para viabilizar e institucionalizar propostas de ensino e pesquisa, assim como novas linhas de investigação. E assim, mesmo diante de tantos desafios, sempre seguiu resoluto e sereno, em busca de tais objetivos, que culminaram na implantação e no desenvolvimento efetivo de pesquisas e disciplinas na área do Pensamento Social no Brasil e da Sociologia da Literatura, abrindo caminho para estruturar, dentre outras, a que hoje definimos como Sociologia da Cultura.

Além de sua obstinação como pesquisador, Correia Dias foi um excepcional professor de Teoria Sociológica Clássica, disciplina que ministrou por inúmeras vezes e, também, de Sociologia Brasileira, disciplina por ele idealizada e introduzida na grade curricular do curso de Sociologia da Universidade de Brasília, muito antes dessa área de pesquisa desfrutar do prestígio hoje alcançado.

Fernando Correia Dias foi um pioneiro? Não, foi um desbravador permanente de novas possibilidades investigativas e interpretativas, que o permitissem observar e compreender fenômenos relativos às construções simbólicas, às produções literárias e à criação de instituições culturais e científicas.

Dedicou, sobretudo, especial atenção às redes de relações dos intelectuais brasileiros, entre si e com o campo institucional no qual se movimentavam.

Particularmente, interessou-se pelas articulações, encontros e desencontros ocorridos entre os intelectuais mineiros e paulistas, cariocas e gaúchos, que fomentaram uma intelligentsia nacional empenhada na formulação dos conceitos de cultura brasileira e tradição nacional, dentre outros.

Nesse sentido, antecipou outra importante ideia dos estudos estruturais e culturais desenvolvidos a partir das décadas de 1970 e 1980, ao perguntar-se como seria possível desvendar a lógica própria à matriz discursiva dos intelectuais modernistas em relação à dinâmica cultural brasileira. 
De modo análogo, Correia Dias procurava observar a historicidade das narrativas sociais, suas modulações através do tempo, preocupando-se, particularmente, com as narrativas relacionadas à construção da nação.

Professor Fernando tinha um jeito mineiro e silencioso de ser e sempre gostou muito das Minas Gerais. Porém, com igual intensidade, gostava do Brasil. Desejou conhecê-lo e trabalhou para compreendê-lo, buscando focalizar outros olhares, outras perspectivas que se distanciassem do viés eurocêntrico, que concebia nosso modo de ser como "atrasado", e a cultura pobre e sem interesse.

Outro marco na trajetória de Correia Dias - e uma das maiores descobertas por ele realizadas enquanto pesquisador - foi a expedição sociológica que empreendeu no universo das manifestações barrocas, em Minas gerais, ao longo de todo o século XVIII, contribuindo decisivamente para a efetiva compreensão de sua dinâmica e riqueza culturais.

Seus trabalhos, artigos e ensaios são, hoje, referência singular aos estudos sobre a temática, como é o caso de seu artigo "A descoberta do barroco pelo movimento modernista".

Embora tenha se dedicado, sobremodo, aos estudos relativos à dinâmica cultural em Minas Gerais, Fernando Correia Dias nunca deixou de interrogar-se sobre uma totalidade histórica mais inclusiva chamada Brasil, em suma, sobre como a nação foi vivida e interpretada. Buscava o particular, o local, o nacional, ou ainda, o universal. Era, talvez, parte da legião de intelectuais que buscava sempre - a compreensão do universal a partir de modos específicos que o homem inventa para viver... Seria o mineiro? O brasileiro? Ou o homem do planeta vivendo num recôndito país tropical?

O certo é que buscava, de forma permanente, compreender dinâmicas culturais singulares, locais e períodos históricos específicos, onde, sabia, jamais perderia o senso da exatidão. O fato é que, em sua trajetória acadêmica, Correia Dias produziu artigos, ensaios e diversos relatórios de pesquisa que muito contribuíram para a compreensão da história do Brasil, aqui incluídas as artimanhas do poder local, a movimentação dos intelectuais e, sobretudo, o lugar que os mesmos ocupavam na estrutura social, inclusive, as narrativas por eles construídas.

Professor Fernando tinha a marca do silêncio e da sabedoria. Não foi um profissional que articulou dispositivos de poder para se inserir e se manter no campo acadêmico da sociologia no Brasil.

Ao contrário, descobriu, como outros mineiros, que "viver é perigoso" 2 e que "tinha uma pedra no meio do caminho" ${ }^{3}$. Como eles, soube lidar com as montanhas, com as curvas e as pedras e, assim, garimpá-las, fossem preciosas ou

1.Guimarães Rosa

2. Carlos Drummond de Andrade 
não! Pedras dos rios - que sempre possuem uma terceira margem -, e que, nessa tessitura entre destino e acaso, rolaram entre Minas Gerais, com suas montanhas profundas, e o Planalto Central, com seus vastos horizontes.

Professor Fernando também foi poeta, ensaísta, sociólogo, pai, amigo - e Professor Emérito da Universidade de Brasília. Sem sombra de dúvidas, sua atuação acadêmica deixou marcas indeléveis no Departamento de Sociologia da UnB.

Aqueles que foram seus alunos, como eu, tiveram o privilégio de conviver com suas ideias e, também, de desfrutar de seu peculiar "jeito de ser" ou, como diríamos hoje, seu modo de subjetivação, tão singular quanto o foco de seus estudos e pesquisas.

As lições deixadas pelo Professor Fernando ficaram e continuarão nos encorajando a observar e pesquisar o que não é hegemônico no campo disciplinar das Ciências Sociais, mas que nos sinaliza sobre o modo de ser de diversas práticas sociais.

Correia Dias, com as pedras do destino, buscou construir um caminho que fosse produtivo para melhor conhecer o Brasil - afinal, a realidade que nos cerca e que nos diz respeito.

Até os seus últimos dias de vida, estudou e pesquisou, não parando de indagarse sobre essa realidade complexa a que chamamos Brasil. Não por acaso, seu último dia de vida coincidiu com o sete de setembro - Independência do Brasil. Espero que um dia, também, saibamos construir um caminho com todas as pedras que nos formaram...

Ao finalizar esta singela homenagem ao querido Professor Fernando, que só nos deixou boas lições, registro a saudade e a amizade de todos aqueles que com ele conviveram e, também, a admiração e o reconhecimento ao mestre que nos ensinou muitas travessias. 